Association for Information Systems

AIS Electronic Library (AISeL)

ICEB 2012 Proceedings

International Conference on Electronic Business

(ICEB)

Fall 10-12-2012

Case Studies on the Exploitation of Crowd-Sourcing with Web 2.0

Functionalities

Khin Mu Yar Soe

Ravleen Kaur

Ravi S. Sharma

Follow this and additional works at: https://aisel.aisnet.org/iceb2012

This material is brought to you by the International Conference on Electronic Business (ICEB) at AIS Electronic Library (AISeL). It has been accepted for inclusion in ICEB 2012 Proceedings by an authorized administrator of AIS Electronic Library (AISeL). For more information, please contact elibrary@aisnet.org. 


\title{
Case Studies on the Exploitation of Crowd-Sourcing with Web 2.0 Functionalities
}

\author{
Khin Mu Yar Soe, Ravleen Kaur and Ravi S. Sharma \\ Wee Kim Wee School of Communication \& Information \\ Nanyang Technological University, Republic of Singapore
}

\begin{abstract}
Crowd-sourcing appears more promising with Web 2.0 functionality and businesses have started using it for a wide range of activities, that would be better completed by a crowd rather than any specific pool of knowledge workers. However, relatively little is known about how a business can leverage on collective intelligence and capture the user-generated value for competitive advantage. This empirical study uses the principle of interpretive field research to validate the case findings with a descriptive multiple case study methodology. An extended theoretical framework to identify the important considerations at strategic and functional levels for the effective use of crowd-sourcing is proposed. The analytic framework uses five Business Strategy Components: Vision and Strategy, Human Capital, Infrastructure, Linkage and Trust, and External Environment. It also uses four Web 2.0 Functional Components: Social Networking, Interaction Orientation, Customization \& Personalization, and User-added Value. By using these components as analytic lenses, the case research examines how successful e-commerce firms may deploy Web 2.0 functionalities for effective use of crowd-sourcing. Prioritization of these functional considerations might be favorable in some cases for the best fit of situations and limitations. In conclusion, it is important that the alignment between strategy and functional components is maintained.
\end{abstract}

Keywords: wisdom of the crowds, collective intelli-

Proceedings of the Twelfth International Conference on Electronic Business, Xi'an, China, October 12-16, 2012, 49-66. gence, open innovation.

\section{Introduction}

With the rise of the Web 2.0 paradigm, the Internet has evolved from a top-down, static platform to a bottom-up fluid generation of ideas for services and applications (Moriarty, 2010). This has empowered its users to share and generate content on media sharing platforms such as blogs and wikis. These platforms create a new path for Internet users to get connected and share information. In broad terms, Weinberg and Pehlivan (2011) defined the Web 2.0 as comprising of computer network-based platforms upon which social media applications/tools function. For instance, Apple offers its own Web 2.0 platform, upon which social media such as iPhone applications may run. The Web 2.0 capabilities of increased pervasiveness of social media and empowered consumer are shaping new business landscape for both Internet and traditional business functions.

The high velocity nature of the rapidly changing Internet's environment (Wirtz et al., 2010), is creating new opportunities as well as challenges for businesses to adjust their operations and adapt their service portfolios to stay competitive. Technology has become an enabler to deliver the business objective rather than the core of the business itself, and the ability to build the business on top of the millions of people using the technology is what makes business powerful and revolutionary. An example of such is eBay, an online auction software program (Moriarty, 2010). Businesses are typically built around a crowd trying 
to harness the wisdom of the distributed individual networks through open calls. This concept has been put into practice since the 1990's (Roth, 2009). This trend was observed and the term "Crowdsourcing" was coined by Jett Howe in the 2006 issue of Wired magazine. Later, in 2008, Howe observed in his book that there is a shadow labor force with more passion than talent and their energy and devotion can provide the fuel for the crowdsourcing engine (Howe, 2008). The contribution of crowd does not pose any limitation to any business activity, ranging from simple task such as data collection, evaluation to complex task such as problem solving, market research, product development, innovation, or even in marketing and promotion (Whitla, 2009). According to Metcalfe (2007), the value of the Web increases with the number of people using it, a phenomenon later coined as 'network effect'. The main driving factors of social media, that can bring distributed individuals together as collective intelligence or wisdom of the crowd, are its social networking and interaction capability (Wirtz, Schilke \& Ullrich, 2010), which allow individuals to create communities and generate content through multi communications i.e., publisher to user, user to user and user to publisher. Social network technologies allow diverse users from all over the world to interact and collaborate with each other as creators of great volume of user-generated content in a virtual community. Examples of social network include social networking sites, hosted services, blogs, wikis, and video sharing sites web application. These collective communities can generate significant amount of traffic, content and increase the value of platform. Web-based community platforms such as YouTube for video sharing, Flickr.com for image sharing, Facebook for both social networking activities and entertainments, and Wikipedia, a pioneer of building mass collaborative up-to-date Encyclopedia were initiated.
According to a report prepared by the Economist Intelligence Unit in 2007 (Economist, 2007), Web 2.0 had significant implications for wide range of businesses and Web 2.0 would be progressing into the mainstream. Based on its survey results, most companies were expecting bigger financial return from new business with Web 2.0 tools for customer acquisition. However, businesses are yet to apply the full potential of Web 2.0 except in marketing area and business intelligence (Schenk \& Guittard, 2011). The American multinational pharmaceutical company Eli Lilly explored the possibilities of Web 2.0 with its Crowdsourcing platform called InnoCreative in 1998 to access the collective intelligence. Only eight years later, the term 'crowdsourcing' was coined and first published by Howe (2006a). Howe (2006b) defined crowdsourcing as a production model of solving distributed problems in the form of open call for solutions by unknown group of solvers or users, also known as the crowd or online communities. The impact of crowdsourcing is apparent with the rise of web 2.0, which revolves around the individuals capable of generating tremendous amount of content behind active browser, and the technology capable of aggregating these disparate and independent ideas (Brabham, 2008). This concept covers a relatively broad range of practices and can imply in different situations. Government and non-profit organizations utilize crowdsourcing as a potential problem-solving tool (Brabham, 2008) and an enormous number of crowdsourcing applications are also currently used in business and social context (Gowdy et al., 2009). In order to solve potential problems and issues, those applications enable organizations for human resource coordination as well as empower creativity and social interactions (Parameswaran \&Whinston, 2007).

In 2004, observers found that digital technology initiatives had significant impact on the economy by introducing a new business environment and creating 
many business opportunities (Lumpkin, \& Dess, 2004). Web 2.0 and social media or social networking empowers technology enterprises to carry out more effective and efficient business operations with endless value-added opportunities. (Parameswaran \& Whinston, 2007). Although the potential of Web 2.0 and social media are widely discussed in the academic and trade literature, the business world has yet to explore and apply the full possibilities of Web 2.0 (Schenk \& Guittard, 2011) to optimize business performance. A similar trend is also observed for the concept and use of crowdsourcing in business practice. Hence, this paper aims to examine the value adding strategies (in the context of business models) that are specific to the notion of crowdsourcing in a Web 2.0 environment. By carrying out qualitative case study comparison of five successful e-business firms - Amazon, Groupon, eBay, Alibaba and iTunes, this paper intends to understand how technology firms leverage on crowdsourcing in context of Web 2.0 to create business value and stay competitive The major objectives are reiterated as follows:

1. To understand the impact of social network technologies and the opportunities of crowdsourcing

2. To analyze the crowdsourcing success factors in the Web 2.0 environment at business, strategic and functional levels.

3. To evaluate the effectiveness of value adding strategic and functional components by identifying the common characteristics in some of the notable successful cases of crowdsourcing at work.

\section{Background Review and Model}

The three essential components identified for crowdsourcing are categorized as follows:

1. Individuals who form the crowd and are providers.
2. Companies which directly or indirectly benefit from the crowd input.

3. Crowdsourcing enablers who form the intermediary platforms. They build a link between the crowd and company.

Social networking platforms provide active web consumer with two-way communication capabilities to produce user-generated content and creativity which can be in the form of fragmented raw data or valuable input. The user-generated content has resulted in a whole range of institutions and businesses to integrate new applications so as to further ease the communication channels. Some of the integrated applications include profile creation, whole websites creation, and video and audio media file creation. In addition, online community users have a high tendency to provide new perspectives on established processes, driving user-generated creativity to be one of the key factors necessary in creating innovative ideas for companies' continuous development. For instance, Nokia Beta Lab gives opportunities for users to share their creative ideas to solve concrete problems and develop new products, designs and technologies (Ewing, 2008).

Thirdly, the main bridge between the customer space and the digital market is the supporting technology platform which enables all crowd activities such as communication, interaction, sourcing, etc. Digital technology space is evolving rapidly and various types of platforms are available to suit different users' and businesses' requirements. The social and technology platforms can be broadly categorized and defined as follows:

1. Social platforms are typically for social driven activities such as networking (e.g., Facebook, LinkIn, Digg) and media sharing (e.g., Flickr, Youtube).

2. Intermediary Platforms are primarily for business activities such as Research and Develop- 
ment, (e.g., Innocentive, TekScout, IdeaConnection, Yet2.com), Marketing, Design and Idea, (e.g., RedesignMe, Atizo, ideaken, Brand Tags, LeadVine), Collective Intelligence and Prediction , (e.g., Intrade,Kaggle, Ushahidi), HR and Freelancers sourcing, (e.g., Spudaroo, ChumBonus, TopCoder, HumanGrid, Amazon Mechanical Turk), Open innovation software, (e.g., spigit, Imaginatik, Napkin Labs, Fellowforce), Open Innovation Services, (e.g., Big Idea Group, Pharmalicensing, Chaordix, DataStation), and Selling and Buying, (e.g., Amazon, eBay, Alibaba).

3. Creative Co-creation platform is for design and other creation examples including Spreadshirt, JuJups, Threadless, Jovoto.

4. Corporate Initiatives platforms are for initiatives such as Product Idea Crowdsourcing, (e.g., Fiat Mio, P\&G Open Innovation Challenge, Kraft, Ideas4Unilever, Dell IdeaStorm, Betavine, BMW Customer Innovation Lab), and Branding and Design Crowdsourcing, (e.g., LEGO Factory, Peugeot, Muji, Fluevog).

5. Peer Production \& P2P production platforms are for peer based production Platforms such as CrowdSpirit, Funding Circle, Linux, Wikipedia, Yahoo Answers.

6. Public Crowdsourcing Platforms are for gathering public input and opinion for broader range of general content(e.g., iBridge Network, Science Commons, Picnic Green Challenge, Eureke medical, German Catholic Church, Fold it, Galaxy Zoo).

Crowdsourcing opportunities can be broadly categorized as information collection, interaction for direct communication, access to collective intelligence, and innovation.

Information Collection: Information gathering opportunities are largely enabled by user generated content through social networking technologies whereby every individual can participate and share/spread the information by through peer Internet users or social platforms, such as Wikipedia. According to the Deutschland Online report published in 2006 (Wirtz et al., 2006), based on a representative study done of 6,347 Inter users, two-thirds of Internet users acknowledged online reference works as trusted knowledge source which is highly relevant to their daily life. It also suggested that information transfer is done via online communities through informal communication modes such as virtual word of mouth (Wirtz et al., 2010). This spreads information among different parties via electronic applications such as review websites, blogs, forums or even e-mail (Kozinets, 1999), allowing businesses to capture the vast amounts of relevant information and content, at very low cost to achieve a few aims (Lumpkin, \& Dess, 2004). The advantage is firstly, it helps to build organizational loyalty and brand recognition as a big part of advertising can be associated with user generated content. Secondly, companies can evaluate the product and process based on direct customer feedback, engaging customers in the product re-engineering process. And finally, information collection would also be useful to aggregate the disparate input and determine the usability and credibility for R\&D process.

Interaction: Frequent online interactions have potential in high level support of help-giving behaviors (Butler, 2001). Effective and direct communication with active user is necessary for dynamic continuous dialogue for product and process feedback, suggestion for improvement, collaboration, and co-innovation. Virtual communities can be described as relational community or the social ties since their members are not physically bound together (Wellman \& Gulia, 1999). According to Jones (1997), four minimum set of conditions are required for active 
virtual community: communicators, sustained membership, interactivity, and virtual space. Idea competition and incentive based participation have been widely discussed as crowdsourcing interaction opportunities, associated with virtual community collaboration.

In idea competitions, a review committee evaluates and selects a winner from the submitted new potential ideas from a targeted public group on specific topic, arrived within limited period of time (Ebner et al., 2008; Vallerand et al., 1998). These competitions have emerged as a promising tool for crowdsourcing and open innovation processes (Walcher, 2007) as it, amongst other factors, encourages contestants to produce winning innovative ideas. They are widely accepted in both literature and practice as an effective method for integrating customers in early innovation activities (Koufteros et al, 2005). However, incentive is the most influential element to ensure potential participants are motivated enough and have to be carefully invested in by organizers. Incentive based participation has been widely accepted as encouraging active user participation which is the fundamental value in Internet businesses creation process. In order to enhance user support, incentives should be involved in creating user-generated value. Websites offering clear incentives to users might benefit most. Reward/value such as cash rewards, rebates or prizes to be won is needed so that contributors have a motive to come back and interact.

Access to collective intelligence: Web 2.0 provides businesses access to the wisdom of the crowds allowing them to push the knowledge boundary of organization (Whitla, 2009). Tapping on the capability of networked crowd through web technologies is known as harvesting Distributed Intellect, which is "a form of universally distributed intelligence, constantly enhanced, coordinated in real time, and resulting in the effective mobilization of skill” (Lévy, 1997
[1995], p.13). Lévy also stated that "no one knows everything, but everyone knows something and all knowledge resides in humanity" and the possibility never ends in crowd. The business can also benefit from distributed problem-solving that is emerging from a large body of intellectual labour at efficient cost (Brabham, 2008). With diffusion of technology and its wide availability, the discovery of value in amateurs is escalated further motivating refreshing, talented individuals to take a chance at entrepreneurship or freelance basis. Additionally, the advent and diffusion of social network technologies also boosts collective creation of knowledge and equips users with active control on quality and quantity of information and knowledge.

Innovation: Recently, the term innovation has become synonymous with organizational strategy for gaining competitive advantage and long-term sustainability. Using advanced Web 2.0 technologies cater to effective interactions such as discussion groups and social networking sites, as essential factors for the future of organizational success and let businesses leverage on knowledge and innovation from an organization's formal boundaries. "Crowdsourcing” has become popular term to describe role of the online communities in discussing ideas since there is "wisdom" embedded in a crowd of individuals that exceeds any individual or small group.

Innovation in public can be seen as the invention of groundbreaking new idea, process or production (Duin et al., 2010).

Chesbrough (2003a) evaluates the Innovation Paradigm shift from "Closed Innovation" at where companies must hold control over the entire process of Innovation as companies cannot be ensured of the quality, availability and capability of others' idea to "Open Innovation" at where a widespread knowledge and collective input of all individual within the reach of cyberspace across cultural barriers that are beyond 
organizations' capability and boundaries (Duin et al.,

innovation.

2010). Figure 1 depicts the funneling effect of open

The Open Innovation Model

In the new model of open innovation, a company commercializes both its own ideas as well as innovations from other firms and seeks ways to bring its in-house ideas to market by deploying pathways outside its current businesses. Note that the boundary between the company and its surrounding environment is porous (represented by a dashed line), enabling innovations to move more easily between the two.

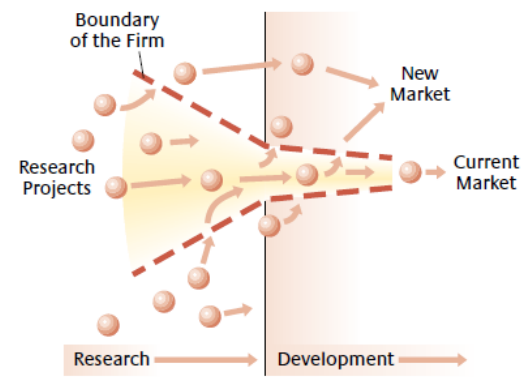

\section{The Closed Innovation Model}

In closed innovation, a company generates, develops and commercializes its own ideas. This philosophy of self-reliance dominated the R\&D operations of many leading industrial corporations for most of the 20th century.

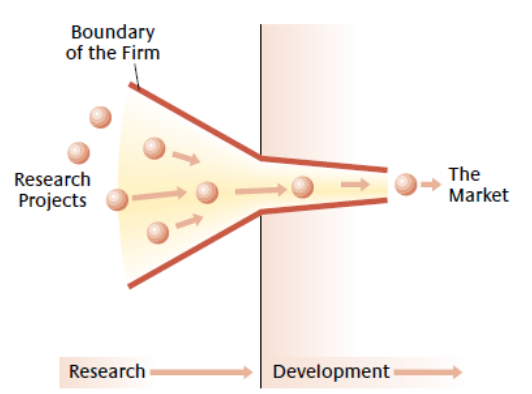

Source: Adopted from Chesbrough, H.W (2003b). The Era of Open Innovation. MIT Sloan Management Review. 44(3), p. 35-41.

Figure 1: Close Innovation vs. Open Innovation.

\section{Case Analysis and Research Method}

The theoretical framework used to analyze the case studies in this paper relates to the understanding of effectiveness of crowdsourcing as business model and draws from a Crowdsourcing Critical Success Factor Model by Sharma (2010) and the Web 2.0 - 4 Factors Model by Wirtz, Schilke and Ullrich (2010). Based on available theoretical frameworks developed by Heeks and Nicholson (2004), Carmel (2003), Farrell (2006) and Balasubramanyam \& Balasubramanyam (1997), Sharma had proposed Vision and Strategy, Human Capital, Infrastructure, Linkages and Trust and External Environment as the critical consideration factors that should be at the core of developing business model for any crowdsourcing initiative to ensure sufficient crowd participation which is key to business success. In 2010, Wirtz, Schilke and Ullrich evaluated social networking, interaction orientation, customization and personalization, and user-added value as four fundamental Web
2.0 characteristics at the implementation phase. This was for businesses to help identify key trends for their own Internet business model and consider these functional dimensions for their specific situation to create value. This has been illustrated in Figure 2.

As there has been very limited research on how business models can evolve to utilize the crowdsourcing effectively, Critical Success Models with Web 2.0 Four Factors in Figure 2 was adapted by integrating the most relevant aspects for analysis and to evaluate the impact of strategic development of crowdsourcing initiative and the effectiveness. The framework is primarily aimed for Internet firms and offers a clearer picture of how crowdsourcing can be strategically adapted into their current business models and the various dimensions to evaluate the effectiveness. Any activities involved should be considered performing based on Web 2.0, particularly in Internet markets.

This research was undertaken according to the 
Interpretive Research Principles proposed by Klein and Myers (1999) to validate the research model and methodology. The overall assessment of Interpretive
Field Studies is summarized and tabulated in Figure 3.

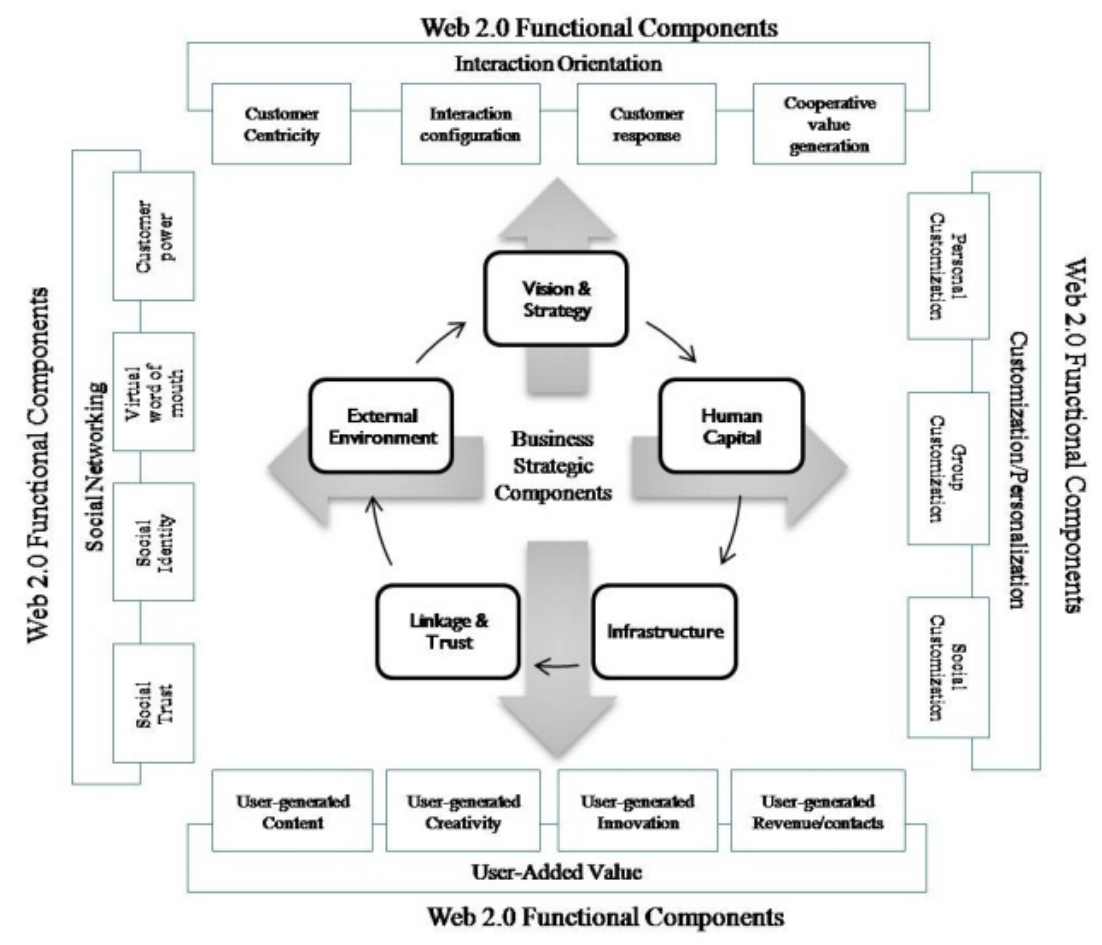

Adapted from Crowdsourcing Critical Success Factor Model by Sharma (2010) and the Web 2.0 - 4 Factors Model by Wirtz, Schilke \& Ullrich (2010).

Figure 2: Crowdsourcing Critical Success Model with Web 2.0 Four Factors

The objective was to gain an understanding of crowdsourcing and its effective usage in Web 2.0 space through the social construction such as documents, shared meanings, consciousness, tools, and other artifacts. The first principle suggests that the most foundation of all interpretive work of a hermeneutic nature is to understand a complex whole from preconceptions about the meanings of its parts and their interrelationships. Studying individual components of similar business activities i.e., established e-commerce, can help broaden the understanding of crowdsourcing and the iterations between the individual business components as parts and the electronic marketplace that determine the wholesome and effective application of Web 2.0.
In the next section, qualitative analysis of five successful e-business firms is carried out to understand how technology firms can further leverage on the web 2.0 space to create their own niche and value.

\section{Results And Analysis}

In this section, the Strategic Components of Amazon, Alibaba, eBay and iTunes are analyzed in Figure 4. All subject cases have a clear and concise vision and strategy, in terms of what services to provide and which segment to focus. At the core of all mentioned businesses is the need to be customer-centric, aiming to provide the excellent user experience.

Infrastructure is complex with highly customized technologies to support the different business 
activities and service functionalities in all subject cases. It plays a major role in streamlining the servic- es, especially on online space.

Figure 4: Comparing Strategic Components of Amazon, Alibaba, eBay \& iTunes

\begin{tabular}{|c|c|c|c|c|}
\hline $\begin{array}{l}\text { Strategic } \\
\text { Components }\end{array}$ & Amazon & Alibaba & eBay & iTunes \\
\hline $\begin{array}{l}\text { Vision \& } \\
\text { Strategy }\end{array}$ & $\begin{array}{l}\text { Clearly define to } \\
\text { focus on excel- } \\
\text { lence customer } \\
\text { service and expe- } \\
\text { rience }\end{array}$ & $\begin{array}{l}\text { Clearly define to } \\
\text { focus on global } \\
\text { trading and inter- } \\
\text { national traders }\end{array}$ & $\begin{array}{l}\text { Clearly define to im- } \\
\text { prove and reinvest on } \\
\text { improving the buyer } \\
\text { experience and seller } \\
\text { economic }\end{array}$ & $\begin{array}{l}\text { Clearly define to } \\
\text { provide seamless } \\
\text { integration and } \\
\text { optimize user ex- } \\
\text { perience }\end{array}$ \\
\hline Human Capital & $\begin{array}{l}\text { Broad targeting } \\
\text { with carefully de- } \\
\text { sign to provide } \\
\text { easy-to-use func- } \\
\text { tionality }\end{array}$ & $\begin{array}{l}\text { Precise targeting } \\
\text { with specifically } \\
\text { design for business } \\
\text { orientated audience }\end{array}$ & $\begin{array}{l}\text { Specific targeting with } \\
\text { particularly designed } \\
\text { Specific targeting with } \\
\text { particularly designed } \\
\text { bidding platform for } \\
\text { buyers and sellers }\end{array}$ & $\begin{array}{l}\text { Generic targeting } \\
\text { with easy to use } \\
\text { design to mass user } \\
\text { base }\end{array}$ \\
\hline Infrastructure & $\begin{array}{l}\text { Complex infra- } \\
\text { structure to support } \\
\text { virtual supply } \\
\text { chain, wide range } \\
\text { of functions and } \\
\text { geographical loca- } \\
\text { tions }\end{array}$ & $\begin{array}{l}\text { Highly customized } \\
\text { technology plat- } \\
\text { form to support } \\
\text { different major } \\
\text { business process } \\
\text { Office in } 70 \text { cities } \\
\text { across the world to } \\
\text { provide additional } \\
\text { business support }\end{array}$ & $\begin{array}{l}\text { Highly important and } \\
\text { carefully designed to } \\
\text { support business activ- } \\
\text { ities in } 31 \text { countries } \\
\text { with extendable sys- } \\
\text { tem functionality }\end{array}$ & $\begin{array}{l}\text { Highly customized } \\
\text { and complex infra- } \\
\text { structure to support } \\
\text { wide range of } \\
\text { products and ser- } \\
\text { vices }\end{array}$ \\
\hline $\begin{array}{c}\text { Linkages \& } \\
\text { Trust }\end{array}$ & $\begin{array}{l}\text { Partnerships with } \\
\text { enterprise clients, } \\
\text { merchants, brands } \\
\text { and service pro- } \\
\text { viders }\end{array}$ & $\begin{array}{l}\text { Strategic partner- } \\
\text { ship with big } \\
\text { business players } \\
\text { and financial insti- } \\
\text { tutions } \\
\text { Trust pass profile } \\
\text { for verification } \\
\text { on community }\end{array}$ & $\begin{array}{l}\text { Highly important and } \\
\text { position as most } \\
\text { trusted company for } \\
\text { privacy (Partnership } \\
\text { with trusted software } \\
\text { service providers and } \\
\text { strict privacy policy) }\end{array}$ & $\begin{array}{l}\text { Business acquisi- } \\
\text { tions, agreements, } \\
\text { collaboration with } \\
\text { major players in } \\
\text { the digital content, } \\
\text { manufactures and } \\
\text { other brands }\end{array}$ \\
\hline $\begin{array}{l}\text { xternal Envi- } \\
\text { ronment }\end{array}$ & $\begin{array}{l}\text { Fit well in virtual } \\
\text { and physical } \\
\text { supply chain, Pro- } \\
\text { vide economic en- } \\
\text { vironment and } \\
\text { system platforms } \\
\text { for other business- } \\
\text { es }\end{array}$ & $\begin{array}{l}\text { Fits in well with } \\
\text { virtual supply } \\
\text { chain environ- } \\
\text { ments between } \\
\text { suppliers, obtain } \\
\text { agreement with } \\
\text { Government bo- } \\
\text { dies }\end{array}$ & $\begin{array}{l}\text { As online market } \\
\text { place, fit in well with } \\
\text { retailers, suppliers and } \\
\text { delivery networks to } \\
\text { streamline operation } \\
\text { and developer com- } \\
\text { munities supports to } \\
\text { enhance the service } \\
\text { functionalities }\end{array}$ & $\begin{array}{l}\text { Promote iTunes as } \\
\text { a digital content } \\
\text { supply chain for } \\
\text { other product and } \\
\text { services offering }\end{array}$ \\
\hline
\end{tabular}

Linkage and trust is another crucial factor in building brand image, customer trust for loyalty, and business collaboration for competitive advantages. Any e-Business which involves financial transaction 
would require establishing the linkage and building trust though strategic partnership and collaboration with other trusted businesses and financial service providers. For iTunes, the business partnership is more towards building better services which could indirectly acquire customer's trust as an excellent lifestyle product and service provider.

Given the similar e-commerce business nature, all subject cases require to have a business supply chain environment which is compatible to operate the required business activities. In the case of Amazon, eBay and iTunes, they provide themselves as a business environment for other individual and business partners to conduct the business using the service that they offered. For the case of Alibaba, governmental support is required for international trading activities.

Next, the functional components, as summarised in Figure 5, are discussed to allow evaluation and identification of the common relevant characteristics on Web 2.0 environment. Social networking is presented in all subject cases, highlighting its relevance in encouraging user participation in e-business environment. All subcomponents of social identity, social trust, virtual word of mouth, and customer power can also be identified in all subject cases. However, re- quired level of trust depends on the nature of business and the accuracy of information varies from one case to another. Customer power is captured in different functionalities and the approach varies based on the business activities.

Only a certain degree of Interaction Orientation can be found in all subject cases. How it has been carried out differs and each business adapts unique approach to ensure there is enough customer interaction to escalate user participation. For example, Amazon promises improved user experience from participation, eBay provides incentive, and iTunes acquires participation with intuitive user-friendliness. The act of balancing customer power and interaction capabilities can be seen in all cases to encourage customer response and this enable cooperative value generation.

Customization and personalization are present at all three levels of personal, group and social across all subject cases, validating that customization and personalization are increasingly becoming the basic requirements in Web 2.0 environment (Wirtz et al., 2010). The strategic approach could be diverse according to the user segmentation.

Figure 5: Comparing functional components of Amazon, Alibaba, eBay and iTunes

\begin{tabular}{|c|c|c|c|c|c|}
\hline \multirow{7}{*}{$\begin{array}{c}\text { Social Identity } \\
\text { Social Net- } \\
\text { working }\end{array}$} & User profile & $\begin{array}{c}\text { User/Business } \\
\text { profile }\end{array}$ & User profile & $\begin{array}{c}\text { User pro- } \\
\text { file/ apple } \\
\text { id }\end{array}$ \\
\cline { 2 - 6 } & Social Trust & $\begin{array}{c}\text { Medium level of } \\
\text { personal informa- } \\
\text { tion accuracy }\end{array}$ & $\begin{array}{c}\text { High level of } \\
\text { personal/business } \\
\text { information ac- } \\
\text { curacy }\end{array}$ & $\begin{array}{c}\text { Medium } \\
\text { Medium level of } \\
\text { personal informa- } \\
\text { tion accuracy } \\
\text { of Mouth } \\
\text { level of } \\
\text { personal } \\
\text { information } \\
\text { accuracy }\end{array}$ \\
\cline { 2 - 6 } & $\begin{array}{c}\text { User rating, re- } \\
\text { view, recommen- } \\
\text { dation }\end{array}$ & User rating & $\begin{array}{c}\text { User rating, re- } \\
\text { view, recommen- } \\
\text { dation }\end{array}$ & $\begin{array}{c}\text { User rating, } \\
\text { review, } \\
\text { social } \\
\text { sharing }\end{array}$ \\
\cline { 2 - 6 } & $\begin{array}{c}\text { Customer } \\
\text { power }\end{array}$ & $\begin{array}{c}\text { Keyword Tag- } \\
\text { ging, Discussion } \\
\text { Board }\end{array}$ & $\begin{array}{c}\text { Supplier rating, } \\
\text { discussion fo- } \\
\text { rum, supplier } \\
\text { matching, and } \\
\text { keyword tagging }\end{array}$ & $\begin{array}{c}\text { Feedback as a } \\
\text { seller and buyers, } \\
\text { detailed seller } \\
\text { rating, } \\
\text { Discussion Board }\end{array}$ & $\begin{array}{c}\text { Rating, } \\
\text { Review and } \\
\text { social } \\
\text { sharing } \\
\text { capability }\end{array}$ \\
\hline
\end{tabular}




\begin{tabular}{|c|c|c|c|c|c|}
\hline \multirow{4}{*}{$\begin{array}{l}\text { Interaction } \\
\text { Orientation }\end{array}$} & $\begin{array}{l}\text { Customer cen- } \\
\text { tricity }\end{array}$ & $\begin{array}{c}\text { Q\&A section } \\
\text { which allows two } \\
\text { way communica- } \\
\text { tion }\end{array}$ & $\begin{array}{l}\text { Highly respon- } \\
\text { sive with } 24 \text { hour } \\
\text { chat and other } \\
\text { educational re- } \\
\text { sources }\end{array}$ & $\begin{array}{l}\text { eBay Live Help, } \\
\text { Answer center } \\
\text { which allows us- } \\
\text { ers to interact }\end{array}$ & $\begin{array}{l}\text { Discussion } \\
\text { board, } \\
\text { compre- } \\
\text { hensive } \\
\text { support } \\
\end{array}$ \\
\hline & $\begin{array}{c}\text { Interaction } \\
\text { Configuration }\end{array}$ & $\begin{array}{l}\text { Improved user } \\
\text { experience for } \\
\text { participation such } \\
\text { as “Amazon Bet- } \\
\text { terizer” tool }\end{array}$ & $\begin{array}{l}\text { No reward for } \\
\text { interaction }\end{array}$ & $\begin{array}{l}\text { Incentive program } \\
\text { available via only } \\
\text { eBay’s partner } \\
\text { network }\end{array}$ & $\begin{array}{l}\text { No reward } \\
\text { for interac- } \\
\text { tion, in- } \\
\text { stead pro- } \\
\text { vide easy to } \\
\text { interact } \\
\text { functional- } \\
\text { ity }\end{array}$ \\
\hline & $\begin{array}{l}\text { Customer Re- } \\
\text { sponse }\end{array}$ & $\begin{array}{l}\text { Open for negative } \\
\text { and positive } \\
\text { feedback }\end{array}$ & $\begin{array}{l}\text { Open for nega- } \\
\text { tive and positive } \\
\text { feedback }\end{array}$ & $\begin{array}{l}\text { Open for negative } \\
\text { and positive } \\
\text { feedback }\end{array}$ & $\begin{array}{l}\text { Customer } \\
\text { response is } \\
\text { limited to } \\
\text { digital con- } \\
\text { tent and } \\
\text { open for } \\
\text { negative } \\
\text { and posi- } \\
\text { tive feed- } \\
\text { back }\end{array}$ \\
\hline & $\begin{array}{l}\text { Cooperative } \\
\text { value genera- } \\
\text { tion }\end{array}$ & $\begin{array}{l}\text { Provide business } \\
\text { opportunities for } \\
\text { every members as } \\
\text { potential business } \\
\text { partner }\end{array}$ & $\begin{array}{l}\text { Provide business } \\
\text { opportunities for } \\
\text { every members } \\
\text { as potential } \\
\text { business partner }\end{array}$ & $\begin{array}{l}\text { Provide business } \\
\text { opportunities for } \\
\text { every members as } \\
\text { potential business } \\
\text { partner }\end{array}$ & $\begin{array}{c}\text { Direct rev- } \\
\text { enue comes } \\
\text { from close } \\
\text { platform } \\
\text { policy, } \\
\text { however, } \\
\text { provide } \\
\text { business } \\
\text { opportuni- } \\
\text { ties for de- } \\
\text { veloper's } \\
\text { community } \\
\text { with annual } \\
\text { charges }\end{array}$ \\
\hline \multirow{3}{*}{$\begin{array}{l}\text { Customization/ } \\
\text { Personaliza- } \\
\text { tion }\end{array}$} & $\begin{array}{l}\text { Personal Cus- } \\
\text { tomization }\end{array}$ & $\begin{array}{l}\text { personal profile } \\
\text { display, recom- } \\
\text { mendation cus- } \\
\text { tomization }\end{array}$ & $\begin{array}{l}\text { Personal profile } \\
\text { display customi- } \\
\text { zation }\end{array}$ & $\begin{array}{l}\text { Personal profile } \\
\text { display customi- } \\
\text { zation }\end{array}$ & $\begin{array}{l}\text { Limited } \\
\text { customiza- } \\
\text { tion to per- } \\
\text { sonal pro- } \\
\text { file display } \\
\end{array}$ \\
\hline & $\begin{array}{l}\text { Group Custo- } \\
\text { mization }\end{array}$ & $\begin{array}{l}\text { Web-store profile } \\
\text { display customi- } \\
\text { zation }\end{array}$ & $\begin{array}{l}\text { Company profile } \\
\text { display customi- } \\
\text { zation }\end{array}$ & $\begin{array}{l}\text { Company profile } \\
\text { display customi- } \\
\text { zation }\end{array}$ & $\begin{array}{l}\text { Followers } \\
\text { and fol- } \\
\text { lowing for } \\
\text { specific } \\
\text { information } \\
\text { dissemina- } \\
\text { tion }\end{array}$ \\
\hline & Social Custo- & Recommendations & Broadcasting & Recommendations & Recom- \\
\hline
\end{tabular}




\begin{tabular}{|c|c|c|c|c|c|}
\hline & mization & $\begin{array}{l}\text { based on previous } \\
\text { purchasing and } \\
\text { other activity data }\end{array}$ & $\begin{array}{l}\text { purchase request } \\
\text { for specific sup- } \\
\text { plier segment }\end{array}$ & $\begin{array}{l}\text { based on previous } \\
\text { purchasing and } \\
\text { other activity data }\end{array}$ & $\begin{array}{l}\text { mendations } \\
\text { based on } \\
\text { previous } \\
\text { purchasing } \\
\text { and other } \\
\text { activity } \\
\text { data } \\
\end{array}$ \\
\hline \multirow{4}{*}{$\begin{array}{l}\text { User-Added } \\
\text { Value }\end{array}$} & $\begin{array}{l}\text { User-generated } \\
\text { content }\end{array}$ & $\begin{array}{l}\text { User review, } \\
\text { recommendation, } \\
\text { user generate in- } \\
\text { formation, appli- } \\
\text { cations }\end{array}$ & $\begin{array}{l}\text { User generated } \\
\text { leads (broad- } \\
\text { casting purchase } \\
\text { request) }\end{array}$ & $\begin{array}{l}\text { User review, } \\
\text { recommendation, } \\
\text { user generate in- } \\
\text { formation }\end{array}$ & $\begin{array}{l}\text { User re- } \\
\text { view, rating } \\
\text { and other } \\
\text { digital con- } \\
\text { tent such as } \\
\text { application }\end{array}$ \\
\hline & $\begin{array}{l}\text { User-generated } \\
\text { creativity }\end{array}$ & $\begin{array}{l}\text { Different web } \\
\text { store design, } \\
\text { layout and func- } \\
\text { tions }\end{array}$ & $\begin{array}{l}\text { Different web } \\
\text { store design, } \\
\text { layout and func- } \\
\text { tions }\end{array}$ & $\begin{array}{l}\text { Customizable web } \\
\text { store, new servic- } \\
\text { es and application } \\
\text { from developer } \\
\text { communities via } \\
\text { open API }\end{array}$ & $\begin{array}{l}\text { Application } \\
\text { from de- } \\
\text { veloper } \\
\text { communi- } \\
\text { ties via Ap- } \\
\text { ple devel- } \\
\text { oper pro- } \\
\text { gram }\end{array}$ \\
\hline & $\begin{array}{l}\text { User-generated } \\
\text { Innovation }\end{array}$ & $\begin{array}{l}\text { Provide web ser- } \\
\text { vices and API }\end{array}$ & not applicable & $\begin{array}{l}\text { Open developer } \\
\text { platform for cus- } \\
\text { tomized services }\end{array}$ & $\begin{array}{c}\text { Complete } \\
\text { developing } \\
\text { eco-system } \\
\text { for devel- } \\
\text { opers }\end{array}$ \\
\hline & $\begin{array}{l}\text { User-generated } \\
\text { revenue/ con- } \\
\text { tacts }\end{array}$ & $\begin{array}{l}\text { Direct revenue } \\
\text { and indirect bene- } \\
\text { fit from user Pur- } \\
\text { chases, virtual } \\
\text { word of mouth, } \\
\text { affiliate programs, } \\
\text { social sharing and } \\
\text { developer com- } \\
\text { munities }\end{array}$ & $\begin{array}{l}\text { Direct revenue } \\
\text { and intangible } \\
\text { benefits from } \\
\text { trader's transac- } \\
\text { tions and pre- } \\
\text { mium member- } \\
\text { ship }\end{array}$ & $\begin{array}{c}\text { Direct revenue } \\
\text { and intangible } \\
\text { benefit from user } \\
\text { Purchases, affili- } \\
\text { ate programs, so- } \\
\text { cial sharing and } \\
\text { developer com- } \\
\text { munities }\end{array}$ & $\begin{array}{l}\text { Direct rev- } \\
\text { enue and } \\
\text { indirect } \\
\text { revenue } \\
\text { from user } \\
\text { purchases, } \\
\text { rental and } \\
\text { developer } \\
\text { communi- } \\
\text { ties } \\
\end{array}$ \\
\hline
\end{tabular}

Amazon, Alibaba, eBay and iTuness, all arranges its functions to generate crowd participation and capture user-added value. All subject cases capture the user-generated content, creativity, and revenue or contacts. However, capturing the user-generated innovation is subjected to the business policy, supporting infrastructure, and technology expertise to manage the process. For example, Alibaba does not adopt the open platform policy to attract external technical knowledge expertise; instead it relies on in-house technical experts.

\section{Discussion of Findings}

The primary outcome of the case analysis is a test of the extended theoretical framework composed of five components at the strategic level and four components at the functional level. The case research allowed for the distillation of design rules, derived from the observations and numerical evaluation, for the effective use of crowdsourcing.

Firstly, each component of the theoretical framework is appropriated to be considered at both the strategic and functional levels. Most importantly, 
businesses need to align the strategic components with functional Web 2.0 components so as to derive the business value from effective crowdsourcing. Businesses can imply the proposed theoretical framework as a basic guidance to identify what the business opportunities are, where they are and how they can approach. It also can help top management and executives to draw insight of how to capture the business value at both strategic as well as functional level by ensuring the strategy is aligned with the functions and activities provided or vice versa.

Secondly, adaptation of theoretical framework is desirable; however, customization would be required. Although the analysis has been carried out on the subject cases which share a similar business domain, each business approaches components of theoretical framework differently. As a result, acquisition of crowd participation and usage of Web 2.0 characteristics may be varied from one case to another. The proposed five business strategy components and four Web 2.0 functional components can be served as important components for the success of crowdsourcing initiatives. However, businesses are required to customize the crowdsourcing adaption to suit their business need, which is the second rule for effective usage of crowdsourcing.

Third, prioritization of proposed components at strategic and functional level is proposed to strengthen the second rule. Prioritization is most favorable for those businesses with limited resources or those businesses experimenting the crowdsourcing opportunity. If applicable, it could even apply to business of rich resources. For further analysis of prioritization, numerical evaluation is carried out with crowdsourcing success determination matrix to identify the most relevant components at the conjunction of strategic and functional components.

The following numerical evaluation has been conducted with an assumption that each individual component of the analytic framework is equally important and need not be customized to suit certain business objective or specific industry domain i.e., for business in general. The overall crowdsourcing success determination matrix is derived based on the relevancy level of observed supporting function and services found in subject cases. The numerical assignment is according to the qualitative comparative judgment, and the accountability of the assigned value is justified by conceptual consideration. The relevancy is categorized at three levels as below and assignment summarized in Figure 6 based on the comparing components results from Figure 4 and 5:

- Medium to High relevancy is given when there are more than services or functions can be identified at both given strategic and functional components.

- Partial relevancy is given when there is at least one service or function can be identified at both given strategic and functional components

- Low relevancy represents is given when there is no service or function can be identified at both given strategic and functional components.

Numerical values are used for the subsequent refining of relevancy to prioritize the strategic and functional components. The score is assigned based on relevancy ranking: Medium to High relevance is given highest score of 3 . Partial relevance is given the score of 2 and low relevance is given the lowest score of 1 . After adding up the value of sub-components under Web 2.0 functional components assigned value, the numeric representation can be finalized as in Figure 6.

Since the max scores are not the same, normalization of each category (business strategic components and web 2.0 functional components) is applied to identify the relevancy level of each components against the defined total relevancy score of 4 $(1+2+3)$. 
After the final scores of functional components are normalized to get $100 \%$ score max, the relevancy score for business strategic components are obtained as shown in Figure 7. Of all strategic components, "Infrastructure" turns out to be most important for crowdsourcing business activities with a highest score of 1.02, which implies that infrastructure is the first aspect an e- business should focus for any crowdsourcing initiatives. Vision \& Strategy places second most important at strategic level for crowd- sourcing initiatives with score of 0.92 . The crowdsourcing initiative should be reflected by Vision and Strategy. Human Capital is in third place with score of 0.86 and thus the targeting should be clearly defined. Linkages \& Trust is the second last component that business can focus for crowdsourcing initiatives with 0.63 and External Environment is the least important strategic component that business can focus for crowdsourcing initiatives.

Figure 5: Crowdsourcing Success Determination Matrix

\begin{tabular}{|c|c|c|c|c|c|c|c|}
\hline \multicolumn{8}{|c|}{ Business Strategic Components } \\
\hline & & & $\begin{array}{l}\text { Vision } \\
\& \\
\text { Strategy }\end{array}$ & $\begin{array}{l}\text { Human } \\
\text { Capital }\end{array}$ & Infrastructure & $\begin{array}{l}\text { Linkages } \\
\text { \& Trust }\end{array}$ & $\begin{array}{c}\text { External } \\
\text { Environment }\end{array}$ \\
\hline \multirow{4}{*}{\multicolumn{2}{|c|}{$\begin{array}{l}\text { Social Net- } \\
\text { working }\end{array}$}} & Social Identity & D & 0 & 0 & $\mathbf{D}$ & O \\
\hline & & Social Trust & 0 & 0 & D & 0 & 0 \\
\hline & & $\begin{array}{l}\text { Virtual Word of } \\
\text { Mouth }\end{array}$ & $\mathbf{D}$ & $\mathbf{D}$ & 0 & 0 & 0 \\
\hline & & Customer power & 0 & 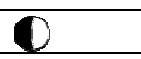 & 0 & 0 & 0 \\
\hline \multirow{4}{*}{\multicolumn{2}{|c|}{$\begin{array}{l}\text { Interaction } \\
\text { Orientation }\end{array}$}} & $\begin{array}{c}\text { Customer cen- } \\
\text { tricity }\end{array}$ & 0 & $\mathbf{D}$ & 0 & $\bigcirc$ & $\bigcirc$ \\
\hline & & $\begin{array}{l}\text { Interaction Con- } \\
\text { figuration }\end{array}$ & 0 & $\bigcirc$ & 0 & $\mathbf{D}$ & $\bigcirc$ \\
\hline & & $\begin{array}{l}\text { Customer Re- } \\
\text { sponse }\end{array}$ & $\mathbf{D}$ & D & 0 & $\bigcirc$ & $\bigcirc$ \\
\hline & & $\begin{array}{c}\text { Cooperative } \\
\text { value generation }\end{array}$ & $\mathbf{D}$ & 0 & O & 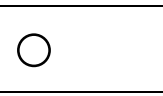 & 0 \\
\hline \multirow{3}{*}{\multicolumn{2}{|c|}{$\begin{array}{l}\text { Customization/ } \\
\text { Personalization }\end{array}$}} & $\begin{array}{c}\text { Personal Cus- } \\
\text { tomization }\end{array}$ & $\boldsymbol{c}$ & 0 & 0 & $\bigcirc$ & O \\
\hline & & $\begin{array}{c}\text { Group Custo- } \\
\text { mization }\end{array}$ & 0 & 0 & 0 & O & $\bigcirc$ \\
\hline & & $\begin{array}{l}\text { Social Custo- } \\
\text { mization }\end{array}$ & 0 & 0 & 0 & $\bigcirc$ & $\bigcirc$ \\
\hline \multirow{4}{*}{\multicolumn{2}{|c|}{$\begin{array}{l}\text { User-Added } \\
\text { Value }\end{array}$}} & $\begin{array}{c}\text { User-generated } \\
\text { content }\end{array}$ & 0 & 0 & 0 & $\mathbf{D}$ & O \\
\hline & & $\begin{array}{l}\text { User-generated } \\
\text { creativity }\end{array}$ & $\mathbf{D}$ & 0 & 0 & D & $\bigcirc$ \\
\hline & & $\begin{array}{l}\text { User-generated } \\
\text { Innovation }\end{array}$ & 0 & 0 & $\mathbf{0}$ & 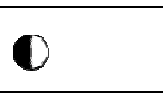 & $\mathbf{D}$ \\
\hline & & $\begin{array}{l}\text { User-generated } \\
\text { revenue/ con- } \\
\text { tacts }\end{array}$ & 0 & $\bigcirc$ & 0 & 0 & 0 \\
\hline
\end{tabular}

\section{Legend}

Medium to High relevance (eBusiness provides more than one supporting funcation and service for each factor) 
Partial relevance (eBusiness provides at least one supporting funcation and service for each factor)

Low relevance (the eBusiness doesn't provide any supporting function and service for each factor)

Figure 6: Numeric representation of Crowdsourcing Success Determination Matrix

Business Strategic components

\begin{tabular}{|c|c|c|c|c|c|}
\hline & $\begin{array}{l}\text { Vision \& } \\
\text { Strategy }\end{array}$ & $\begin{array}{l}\text { Human } \\
\text { Capital }\end{array}$ & Infrastructure & $\begin{array}{c}\text { Linkages \& } \\
\text { Trust }\end{array}$ & $\begin{array}{l}\text { External En- } \\
\text { vironment }\end{array}$ \\
\hline Social Networking & 10 & 6 & 10 & 9 & 10 \\
\hline Interaction Orientation & 10 & 8 & 12 & 5 & 6 \\
\hline $\begin{array}{c}\text { Customization/ Perso- } \\
\text { nalization }\end{array}$ & 6 & 9 & 9 & 3 & 3 \\
\hline User-Added Value & 11 & 10 & 9 & 9 & 5 \\
\hline
\end{tabular}

Table 7: Relevancy Score for Business Strategic Components

Business Strategic components

\begin{tabular}{|c|c|c|c|c|c|c|}
\hline & $\begin{array}{l}\text { Vision \& } \\
\text { Strategy }\end{array}$ & $\begin{array}{l}\text { Human } \\
\text { Capital }\end{array}$ & Infrastructure & $\begin{array}{l}\text { Linkages } \\
\text { \& Trust }\end{array}$ & $\begin{array}{l}\text { External En- } \\
\text { vironment }\end{array}$ & Total \% \\
\hline $\begin{array}{l}\text { Social Network- } \\
\text { ing }\end{array}$ & $22 \%$ & $13 \%$ & $22 \%$ & $20 \%$ & $22 \%$ & $100 \%$ \\
\hline $\begin{array}{l}\text { Interaction } \\
\text { Orientation }\end{array}$ & $24 \%$ & $20 \%$ & $29 \%$ & $12 \%$ & $15 \%$ & $100 \%$ \\
\hline $\begin{array}{l}\text { Customization/ } \\
\text { Personalization }\end{array}$ & $20 \%$ & $30 \%$ & $30 \%$ & $10 \%$ & $10 \%$ & $100 \%$ \\
\hline $\begin{array}{l}\text { User-Added Val- } \\
\text { ue }\end{array}$ & $25 \%$ & $23 \%$ & $20 \%$ & $20 \%$ & $11 \%$ & $100 \%$ \\
\hline Score & 0.92 & 0.86 & 1.02 & 0.63 & 0.58 & 4 \\
\hline
\end{tabular}

Table 8: Relevancy Score for Web 2.0 Functional Components

Business Strategic components

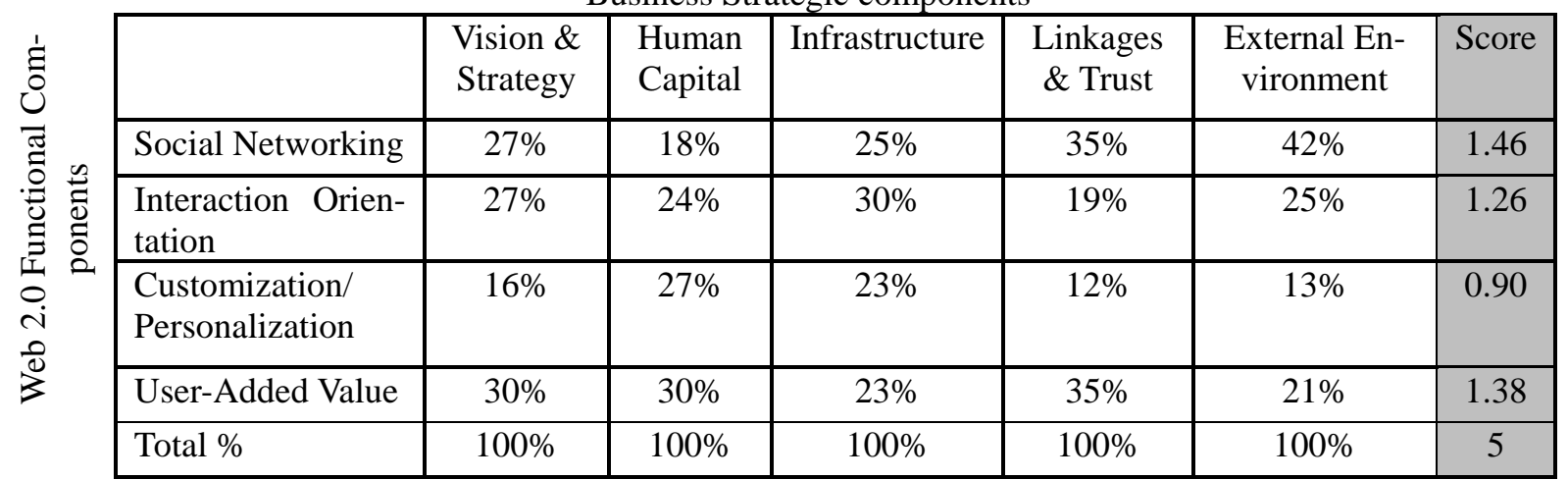

To obtain web 2.0 functional relevancy score (see Figure 8), the final score of business strategic components are normalized to get $100 \%$ score max. At the functional level, as shown in Figure 8, Social Networking is the most crucial functionality with highest score of 1.46 and the result is aligned with the growing social web. The ability to capture the "User-Added Value" should be second most important consideration at the score of 1.38. "Interaction Orientation” ranked as third most important at the score of 1.26, followed by customization/personalization at the least score of 0.90 . 


\section{Conclusion}

This paper has presented the results of a qualitative interpretive field research for defining the extended analytic theoretical framework of Crowdsourcing Critical Success Model with Four Web 2.0 Factors. The identification of five Business Strategy Components (Vision and Strategy, Human Capital, Infrastructure, Linkage, and Trust and External Environment) and four Web 2.0 Functional Components (Social Networking, Interaction Orientation, Customization \& Personalization, and User-added Value) have been derived to address the research question of the important business and functional components that contribute to success of crowdsourcing initiatives.

Three design rules for effective usage of crowdsourcing were formulated based on quality of comparative judgment, and on conceptual consideration. The first rule requires an e- business to align the strategic components and functional Web 2.0 components. The second rule suggests that crowdsourcing adaptation should be customized to suit the different business requirements. The third rule of prioritization supports business with effective crowdsourcing possibilities under constraints.

Practitioners from academic can contribute to specific under-investigated areas indicated by the proposed framework and link to other business domains. It is crucial to note that the study is limited to a particular business scenario of e-commerce and the insight drawn is most applicable to similar business domains. However, it does not set limit for other business or non-profit sectors and other business activities, and further research is recommended to explore the possibility in non-business field such as politics, government and NGOs. The validity of findings is subjected to the accuracy of utilized secondary data sources. To strengthen the analysis and ease the weakness posted by qualitative consideration and comparative judgement from a mere observation, primary data can be sourced by conducting an extensive survey, interview or focus groups study. Practitioners from business are expected to benefit from this study, especially de-novo technology firms with an intention to embark on crowdsourcing initiatives or to adjust the current services offering to explore the crowdsourcing opportunities.

\section{References}

[1] Alibaba. (2011). Culture and Values. Retrieved on Aug 08, 2011, from http://www.alibaba.com/ about/en/AboutOurCompany/cul_val.html

[2] Alvesson, M., \& Willmott, H. (1992a). Critical Management Studies. London:Sage Publications.

[3] Alvesson, M., and Willmott, H. (1992b). On the Idea of Emancipation in Management and Organization Studies," Academy of Management Review, 17(3), 432-464.

[4] Anklam, P. (2009). Ten years of net work. The Learning Organization, 16(6), 415-426.

[5] Balasubramanyam, V.N., \&Balasubramanyam, A. (1997). International trade in services: The case of India's computer software. World Economy, 20(6), 829-843.

[6] Brabham, D. C. (2008). Crowdsourcing as a model for problem solving: An introduction and cases. Convergence: The International Journal of Research into New Media Technologies, 14(1), 75-90.

[7] Brabham, D. C. (2009). Crowdsourcing the public participation process for planning projects. Planning Theory, 8(3), 242-262.

[8] Butler, B. S. (2001). Membership size, community activity, and sustain-ability: A resource-based model of online social structures. Information Systems Research,12(4), 346- 362.

[9] Carmel, E. (2003). The New Software Exporting Nations: Success Factors. Electronic Journal on Information Systems in Developing Countries, 
13(4), 1-12.

[10] Chaffey, D. (2010). eBay Case Study E-commerce. Retrieved on Aug 08, 2011 from http://www.davechaffey.com/E-commerce-Intern et-marketing-case-studies/eBay-case-study-e-co mmerce

[11] Chesbrough, H.W (2003a). Open Innovation: The New Imperative for Creating and Profiting from Technology. Harvard Business School Press, Boston, MA.

[12] Chesbrough, H.W (2003b). The Era of Open Innovation. MIT Sloan Management Review. 44(3), 35-41.

[13] Cone, E. (2006). Inside eBay’s Innovation Machine. Retrieved on Aug 08, 2011 from http://www.cioinsight.com/c/a/Case-Studies/Insi de-eBays-Innovation-Machine/

[14] Datamonitor. (2010, Aug). eBay Inc.: Company profile. Retrieved from Business Insights database.

[15] Datamonitor. (2010, Dec). Alibaba.com Limited.: Company profile. Retrieved from Business Insights database.

[16] Datamonitor. (2011a, Oct). Amazon.com, Inc.: Company profile. Retrieved from Business Insights database.

[17] Datamonitor. (2011b, Oct). Apple, Inc.: Company profile. Retrieved from Business Insights database.

[18] Davison R.M \& Xiaojuan, O. C. (2008).Guanxi, knowledge and online intermediaries in China. Chinese Management Studies, 2(4), 281-302.

[19] Donner, J. (2009). Mobile-based livelihood services in Africa: pilots and early deployments. In M. Fernández-Ardèvol \& A. Ros (Eds.), Communication technologies in Latin America and Africa: A multidisciplinary perspective, 37-58.

[20] Duin, H., M. Fradinho, Seifert, M., and Thoben, K. (2010). Support for Innovation Processes in
Collaborative Networks. Collaborative Networks for a Sustainable World (95-102). L. Camarinha-Matos, X. Boucher and H. Afsarmanesh, Springer Boston.

[21] Ebner, W., Leimeister, M., Bretschneider, U., \& Krcmar, H. (2008).Leveraging the wisdom of crowds: Designing an IT-supported ideas competition for an ERP software company.In R.H. Sprague Jr. (ed.), Proceedings of the Forty-First Annual Hawaii International Conference on System Sciences.Los Alamitos, CA: IEEE Computer Society Press.

[22] Economist (The) (2007) Serious business: Web 2.0 goes corporate. A report from the Economist Intelligence Unit, Sponsored by FAST, retrieved Aug 01, 2011 from http://graphics.eiu.com/upload/eb/fast_report.pdf

[23] Ewing, J. (2008). User-generated Creativity: How Nokia Users Drive Innovation, retrieved Aug 01, 2011, from http://www.businessweek. com/globalbiz/content/apr2008/gb20080430_76 4271.htm

[24] Farrell, D. (2006). Smarter Offshoring. Harvard Business Review, 84(6), 84-92.

[25] Forester, J. (1992). Critical Ethnography: On Field Work in an Habermasian Way. In

[26] M. Alvesson, and H. Willmott (eds.), CriticalManagement Studies (pp. 46-65). London: Sage Publications.

[27] Flyvbjerg, B. (2006). Five Misunderstandings About Case Study Research. Qualitative Inquiry, 12(2), 219-245.

[28] Gowdy, H., Hilderbrand, A., Plana, D. L., \& Campos, M. M. (2009). Convergence: How five trends will reshape the social sector. Los Angeles: La Piana Consulting. Retrieved Dec 28, 2011, from http://www.lapiana.org/downloads/Convergence_Report_2009.pdf

[29] Heeks, R., \& Nicholson, B. (2004). Software 
Export Success Factors and Strategies in Developing and Transitional Economies. Competition and Change, 8(3), 267-302.

[30] Heidegger, M. (1962). Being and Time. Oxford: Basil Blackwell.

[31] Howe, J. (2006a). Crowdsourcing: A Definition, Crowdsourcing: Tracking the Rise of the Amateur (weblog, 2 June). Retrieved Aug 01, 2011, from http://crowdsourcing.typepad.com/cs/2006/ 06/crowdsourcing_a.html

[32] Howe, J. (2006b). The Rise of Crowdsourcing.Wired 14(06). Retrieved July 25, 2011, from http://www.wired.com/wired/archive/14.06/crow ds.html

[33] Howe, J. (2008). Crowdsourcing: Why the Power of the Crowd Is Driving the Future of Business (Vol. unedited e, p. 320). Crown Business.

[34] Husserl, E (1970). Logical Investigations. London: Routledge and Kegan Paul.

[35] Husserl, E (1982). Ideas Pertaining to a Pure Phenomenology and to a Phenomenological Philosophy. Boston: Kluwer.

[36] Ireland, R.D ., \& Hitt, M. A. (1999) Achieving and maintaining strategic competitiveness in the 21st century: The role of strategic leadership. Academy of Management Executive, (13,1), 4357.

[37] Javalgi, R., B. Cutler, \& Todd, P. (2004). An Application of an Ecological Model to Explain the Growth of Strategies of Internet Firms: The Cases of eBay and Amazon. European Management Journal, 22(4), 464-470.

[38] Jones, Q. (1997). Virtual communities, virtual settlements and cyber-archaeology: A theoretical outline. Journal of Computer-Mediated Communications, 3(3).

[39] Klein, H. K., \& Myers, M. D. (1999). A Set of Principles for Conducting and Evaluating Interpretive Field Studies in Information Systems.
MIS Quarterly, 23(1), 67-93.

[40] Koufteros, X., Vonderembse, M., \& Jayaram, J. (2005) .Internal and external integration for product development: The contingency effects of uncertainty, equivocality, and platform strategy. Decision Sciences, 36(1), 97-133.

[41] Kozinets, R.V. (1999). E-Tribalized Marketing?The Strategic Implications of Virtual Communities of Consump-tion. European Management Journal, 17(3), 252-264.

[42] Lee, A.S. (1989). A Scientific Methodology for MIS Case Studies. MIS Quarterly, 13(1), 33-52.

[43] Lévy, P. (1997 [1995]). Collective Intelligence: Mankind's Emerging World in Cyberspace. (R. Bononno, Trans.) New York: Plenum.

[44] Lumpkin, G. T. and Dress, G.G. (2004). E-Business Strategies and Internet Business Models: How the Internet Adds Value. Organizational Dynamics, 33(2), 161-173.

[45] Lyytinen, K. (1992). Information Systems and Critical Theory. In M. Alvesson and H. Willmott (Eds.), Critical Management Studies (pp. 159-180). London: Sage Publications.

[46] Metcalfe, R. (2007). It's all in your head. Forbes, 179, 52-56.

[47] Mingers. J. C. (1981). Towards An Appropriate Social Theory for Applied Systems Thinking: Critical Social Theory and Soft Systems Methodology. Journal of Applied Systems Analysis (7), 41-49.

[48] Moriarty, G. L. (2010), Psychology 2.0: Harnessing social networking, user-generated content, and crowdsourcing. Journal of Psychological Issues in Organizational Culture, 1(2), 29-39.

[49] Parameswaran, M., \&Whinston, A. B. (2007). Social Computing: An Overview. Communications of the Association for Information Systems, 19 (37), 762-780. 
[50] Myers, M. D., and Young, L.W.(1997). Hidden Agendas, Power, and Managerial Assumptions in Information Systems Development: An Ethnographic Study. Information Technology and People, 10(3), 224-240.

[51] Ngwenyama, O. K. (1991). The Critical Social Theory Approach to Information Systems: Problems and Challenges. In H-E. Nissen, H. K. Klein, and R. A. Hirschheim (Eds.), Information Systems Research: Contemporary Approaches and Emergent Traditions (pp. 267-280). Amsterdam: North-Holland.

[52] Orlikowski, W. J., \& Baroudi, J. J. (1991). Studying Information Technology in Organizations: Research Approaches and Assumptions. Information Systems Research, 2(1), 1-28.

[53] Ricoeur, P. (1976). Hermeneutics and the Human Sciences. Cambridge, UK: Cambridge University Press.

[54] Roth, S. (2009). How far can crowdsourcing go? Discussing trans-national open innovation strategies against the brain drain from CIS countries. The Social Sciences and Humanities: Research Trends and Collaborative Perspectives (pp. 285-300). ISS RAS.

[55] Schenk, E., \& Guittard, C. (2011). Towards a characterization of crowdsourcing practices. Journal of Innovation Economics, 7(1), 93. De Boeck Université.

[56] Sharma, A. (2010). Crowdsourcing Critical Success Factor Model: Strategies to harness the collective intelligence of the crowd. Working Paper. London School of Economics, UK.. Retrieved June 20, 2011, from http://irevolution.files.wordpress.com/2010/05/working-paper1.pdf

[57] Truste (2009). Press Release: 2009 Most Trusted Companies in Privacy. Retrieved Aug 08, 2011, from http://www.truste.com/about_TRUSTe/ press-room/news_truste_2009_most_trusted_co mpanies_for_privacy

[58] Turoczy, R. (2008). Obama's Social Media Advantage, Act II. ReadWriteWeb. Retrieved Dec 28, 2011, from http://www.readwriteweb.com/ archives/obamas_social_media_advantage.php

[59] Vallerand, R.J. and Fortier, M.S. (1998). Measures of Intrinsic and Extrinsic Motivation in Sport and Physical Activity: A Review and Critique, J.L. Duda (ed.), Advances in Sport and Exercise Psychology Measurement (pp. 81-101). Morgantown, WV: Fitness Information Technology.

[60] Walcher, P.D. (2007). The Ideas Competition as an Approach for Active Customer Integration. Wiesbaden: Deutscher Universitäts-Verlag.

[61] Walsham, G. (1995). Interpretive case studies in IS research: nature and method. European Journal of Information Systems, 4(2), 74-81.

[62] Weinberg, B. D. and E. Pehlivan (2011). Social spending: Managing the social media mix. Business Horizons, 54(3), 275-282.

[63] Wellman, B., \&Gulia, M. (1999). Virtual communities as communities: Net surfers don't ride alone. In M. A. Smith, \& P. Kollock (Eds.), Communities in cyberspace (pp. 167- 194). London: Routledge.

[64] Wirtz, B. W., Burda, H. and Raizner, W. (2006). Deutschland Online 4. The Future of Broadband Internet. Retrieved August 12, 2012, from http://www.studie-deutschland-online.de/do4en/ DO4-Berichtsband_e.pdf

[65] Wirtz, B. W., O. Schilke, Ullrich. S. (2010). Strategic Development of Business Models: Implications of the Web 2.0 for Creating Value on the Internet. Long Range Planning , 43(2-3), 272-290.

[66] Whitla, P. (2009). Crowdsourcing and Its Application in Marketing Activities. Contemporary Management Research, 5(1): 15-28. 